\section{Radiofrequency \\ Thermocoagulation of Ganglion Impar in the Management of Coccydynia: Preliminary Results}

\section{Koksidinin Tedavisinde Gangliyon İmparın Radyofrekans Termokoagulasyonu: İlk Sonuçlar}

\begin{abstract}
AIM: Coccydynia is a painful condition affecting quality of life. The majority of patients can be successfully treated by non-surgical means. Chemical neurolysis, cryoablation and radiofrequency thermocoagulation (RFT) of ganglion impar are also used in the treatment of visceral pelvic pain. We analyzed the efficacy of RFT of ganglion impar in patients with chronic coccydynia.

MATERIAL and METHODS: We retrospectively analyzed the collected data of 10 patients with chronic coccydynia (pain $>6$ months) who were treated by RFT of the ganglion.

RESULTS: The mean age of the patients was $49.2 \pm 14.4$ (range 27-77) with 8 females $(80 \%)$ and 2 males (20\%). The average follow-up duration was $9.1 \pm 1.2$ months. Statistically significant differences were observed between the preprocedure and post-procedure VNSs $(\mathrm{p}<0.01)$. Improvements in VNS scores were correlated with improvements in the EQ-5D scores. Midterm evaluation after the treatment (6 months) revealed that $90 \%$ of the patients had a successful outcome and $10 \%$ were deemed failures.

CONCLUSION: Our data suggest that RFT destruction of ganglion impar in patients with chronic coccydynia has an effective outcome and patients responding to RFT have significantly lower post-RFT pain scores. The most important factors determining success of this procedure is strict patient selection criteria and the technique of the procedure.
\end{abstract}

KEYWORDS: Chronic coccydynia, Ganglion impar, Outcome, Patient selection, Radiofrequency thermocoagulation, Technique

\section{ÖZ}

AMAÇ: Koksidini hayat kalitesini etkileyen ağrılı bir rahatsızlıktır. Hastaların çoğunluğu konservatif metodlarla başarıyla tedavi edilebilirler. Kimyasal nörolizis, kiryoablazyon ve ganglion imparın radyofrekans termokoagulasyonu da visseral pelvik ağrının tedavisinde kullanılırlar. Biz de, kronik koksidinisi olan hastalarda ganglion imparın radiofrekans termokoagulasyonunun (RFT) etkisini araştırdık.

YÖNTEM ve GEREÇ: Kronik koksidinisi (ağrı > 6 ay) olan ve ganglion impar RFT'u yapılan 10 hastayı retrospektif olarak inceledik.

BULGULAR: Hastaların ortalama yaşı $49.2 \pm 14.4$ (27-77) idi, 8'i (\%80) kadın, 2'si (\%20) erkekti. Ortalama takip süresi $9.1 \pm 1.2$ aydı. İşlem öncesi ve sonrası VNS'lerde anlamlı farklılıklar gözlendi $(p<0,01)$. VNS değerlerindeki iyileşmeler EQ-5D değerlerindeki iyileşmelerle korreleydi. Tedavi sonrası orta dönem (6 ay) değerlendirmede hastaların \%90'ında başarılı sonuç, \%10'unda başarısızlık görülmüştür.

SONUÇ: Kronik koksidinili hastalarda ganglion imparın RFT ile tahribatı başarılı sonuç vermektedir ve RFT'e yanıt veren hastaların RFT işlemi sonrası ağrı değerleri anlamlı olarak azalmaktadır. Ek olarak, hasta seçimi ve işlem tekniği bu işlemin başarısındaki en önemli faktörlerdir.

ANAHTAR SÖZCÜKLER: Gangliyon impar, Hasta seçimi, Kronik koksidini, Radyofrekans termokoagulasyon, Sonuç, Teknik

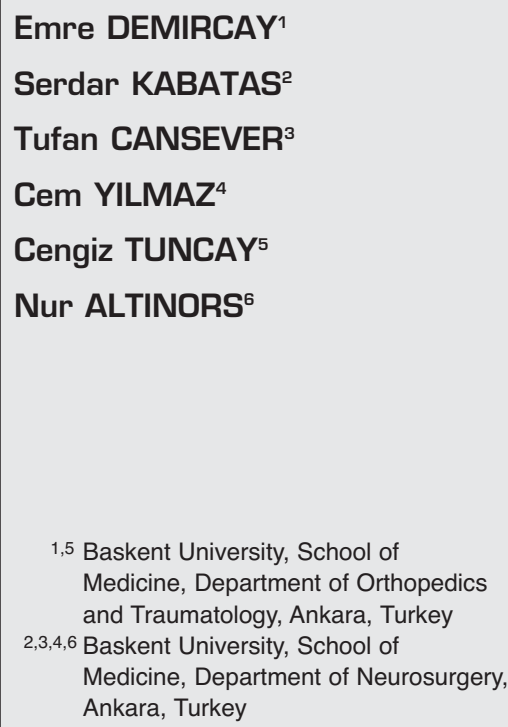
Medicine, Department of Orthopedics and Traumatology, Ankara, Turkey

2,3,4,6 Baskent University, School of Medicine, Department of Neurosurgery, Ankara, Turkey

Received : 10.12.2009

Accepted : 07.03.2010

Correspondence address: Emre DEMIRCAY

Department of Orthopedics and Traumatology, Baskent University, Istanbul Hospital, Oymaci Sokak No:7, 34662 Uskudar, Istanbul,TURKEY

Phone : +90 2165541500

Fax : +902166519746

E-mail : emredemircay@hotmail.com 


\section{INTRODUCTION}

Coccydynia is a painful condition of the coccyx. Common coccydynia is often related to trauma, childbirth or unknown etiology. Typically discomfort is felt in the sitting position and when rising from the sitting position. Women are affected more frequently than men $(3,14)$. It is a relatively rare condition that usually responds well to antiinflammatory drugs, and wedge or doughnut cushions. Patients with persisting pain for more than 3 - 6 months may require multimodal treatment with injections. Surgery may be warranted in some patients who continue to have disabling coccygeal pain despite various non-operative treatment modalities. Injections for coccydynia include corticosteroid injections into the caudal epidural space or into the sacrococcygeal junction $(5,8,14)$. Local anesthetic injections to block the ganglion impar (ganglion of Walther) can be administered with successful results $(1,11)$. Chemical neurolysis and cryoablation are also used in the treatment of visceral pelvic pain $(6,12)$. Destruction of ganglion impar using radiofrequency lesioning is another option (11). In this study, we aimed to evaluate the effectiveness of radiofrequency thermocoagulation (RFT) of ganglion impar in patients with chronic coccydynia using the parameters of pain and healthrelated quality of life.

\section{MATERIAL and METHODS}

\section{Patient selection}

Ten patients who were treated with RFT of ganglion impar for chronic coccydynia were enrolled in this study. The demographic data of the patients are shown in Table I. All patients signed an informed consent before the procedure. There were 2 $(20 \%)$ males and $8(80 \%)$ females with a mean age of $49 \pm 14.43$ years (range: $27-77$ ). A history of a fall involving direct trauma to the coccygeal area was present in $4(40 \%)$ patients.

Inclusion criteria were; chronic debilitating coccyx pain nonresponsive to any conservative treatment such as nonsteroidal anti-inflammatory drugs (NSAIDs), seat cushions, physical therapy, and local injections for more than 6 months. All the patients had at least $80 \%$ pain relief lasting 2-6 hours following diagnostic ganglion impar block with 10 $\mathrm{ml}$ of $0.25 \%$ bupivacain. Patients with pilonidal cysts, radicular symptoms and rectal, gynecologic
Table I: Demographic Data of the Patients

\begin{tabular}{|c|c|c|l|}
\hline Patient No \# & Age & Gender & Trauma \\
\hline 1 & 27 & M & YES $(10$ y) \\
\hline 2 & 47 & F & YES $(4$ y) \\
\hline 3 & 53 & F & YES $(2$ y) \\
\hline 4 & 39 & F & NO \\
\hline 5 & 43 & F & NO \\
\hline 6 & 65 & F & NO \\
\hline 7 & 52 & F & NO \\
\hline 8 & 36 & M & YES $(1$ y) \\
\hline 9 & 77 & F & NO \\
\hline 10 & 53 & F & NO \\
\hline
\end{tabular}

and pelvic disorders were excluded. All patients had focal tenderness over the coccyx. Pregnant or lactating women and patients who were known to be sensitive to local anesthetics were also excluded from the study. All the patients were extensively investigated by full clinical examination, plain radiographs of the lumbosacral spine and coccyx, and magnetic resonance imagining (MRI) of the lumbar and sacral spine by the same authors (E.D. and S.K.). Lumbosacral x-rays were evaluated for degenerative diseases, spondilolisthesis, congenital anomalies, and sacroiliac joint pathology. Coccygeal $x$ rays would reveal fractures, dislocations, congenital anomalies or spicules. Lumbar and sacral MRI investigations of the spine were helpful to evaluate if the pain was referred from a more proximal spinal segment, and if there was another accompanying soft tissue pathology. Additionally, MRI would also demonstrate inflammation of the sacrococcygeal area (Figure 1).

\section{Diagnostic blocks}

Potential risks of diagnostic blocks including allergic reaction, bleeding, and infection were discussed with the patients and consent forms were obtained. The procedures were performed in the operation theatre equipped with a planar fluoroscope (SiemensTM, Münich, Germany) while the patients were prone, and aseptic preparation was done as usual. Sedation or neurolept anesthesia was not used because patient cooperation was needed during the procedure. The injection level was 


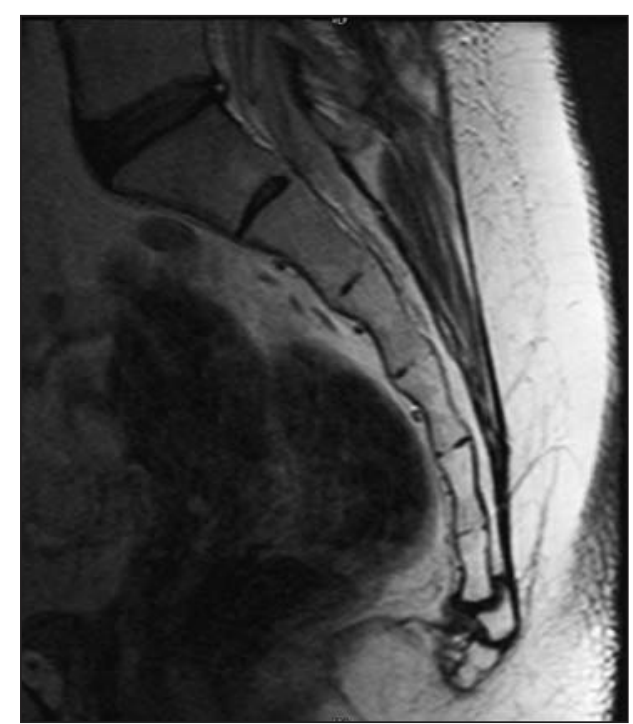

Figure 1: MRI view of posterior luxation of $\operatorname{coccy} x$.

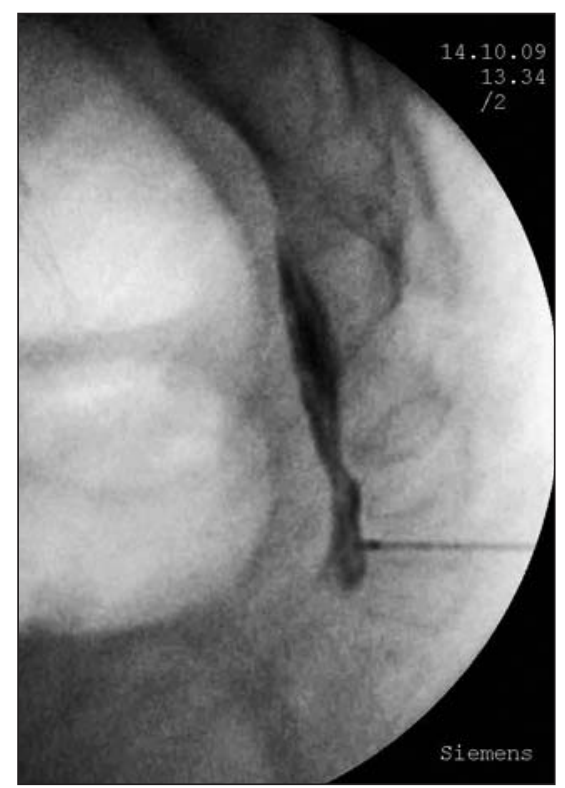

Figure 2: Needle placement through C1-C2 intercoccygeal junction. Contrast distribution confined to the anterior of the coccyx and sacrum covering the location of ganglion impar.

fluoroscopically determined, and a wheal of local anesthesia was raised at the site of needle insertion. A 9-cm long, 21-gauge spinal needle (StimuquikTM (insulated peripheral nerve block needle]; Arrow International, PA, USA) was directed to the sacrococcygeal junction or first intercoccygeal junction under the guidance of C-arm fluoroscope. The needle was advanced through the junction until the tip was placed just anterior to the first intercoccygeal or sacrococcygeal junction. The position of the needle tip was confirmed by injecting
$1 \mathrm{ml}$ of radio-opaque dye into the retroperitoneal space. The spread of the dye gives a "reverse comma" appearance in the lateral view (Figure 2). The C1 - C2 intercoccygeal junction was used for needle placement while the sacrococcygeal junction was tried if it was fused or the "reverse comma" appearance could not be seen or an effective block could not be achieved. The block was performed by injecting $0.25 \%$ bupivacaine.

\section{Radiofrequency thermocoagulation}

Ten of the patients that received diagnostic ganglion impar blocks and reported a temporary relief of their symptoms of at least $80 \%$ were selected for radiofrequency thermocoagulation. The technique for the procedure was the same as the diagnostic ganglion impar block previously described by Reig et al. (11). Once the electrode positioning was confirmed, the electrical stimulation was performed and the patient was asked to define any pain he/she might be feeling. The denervation process started after the patients confirmed the pain was like the original pain as before the diagnostic block. The patients were encouraged to tell any unpleasant feelings during the procedure so that we could stop. Radiofrequency lesioning was performed at $80^{\circ} \mathrm{C}$ for 120 seconds. The patients were given no extra medication after the procedure and they were discharged from the hospital either the same day or the following day.

\section{Evaluation of pain and health-related quality of life}

The patients enrolled in the study were asked to define their pain using a Visual Numeric Pain Scale (VNS) ranging from 0 to 10 (0 represents no pain and 10 represents the worst pain imaginable) before and after the procedure and at their follow up visits.

They were also asked to define their health status using the descriptive system of health-related quality of life states (EQ-5D), which is a questionnaire standardized form to describe and evaluate health-related quality of life. It describes the patient's health status using five domains (mobility, self-care, usual activities,pain/discomfort, and anxiety/depression). Each dimension has three levels of severity with level 1 indicating no problem at all, level 2 some problems, and level 3 extreme problems. 


\section{Statistical Analysis}

Data were analyzed by SPSS version 15.0 software. P-values for correlation rates of the pre-op and follow-up VNS and EQ-5D scores were determined using the Pearson Correlation test and 95\% confidence intervals were computed. Significance was set at $\mathrm{p}<0.05$ with a $95 \%$ confidence interval. The effects of the variables (gender, age, trauma, pre-op VNS, post-op VNS, 1st month VNS, 6th month VNS, pre-op EQ-5D, 1st month EQ-5D and 6th month EQ-5D compared to the pre-op VNS and EQ-5D) on the immediate, short-term and longterm results of the patients were analyzed using the linear regression test.

\section{RESULTS}

None of the patients had complications. All of them fully completed follow-up visits. The ages of the patients ranged from 27 to 77 years $(49.20 \pm 14.43$ years) with 8 females (80\%) and 2 males (20\%). The mean follow-up duration was 9.1 \pm 1.2 months. Individual and mean VNS and EQ-5D scores are given in Table II. One patient who had 33.3\% VNS score improvement (9 to 6) at the 6th month followup was considered as a failure, and one patient who had 50\% VNS score improvement (8 to 4 ) at the 6th month follow up considered a successful result.

Table II: Mean VNS and EQ-5D Scores

\begin{tabular}{|l|c|c|}
\hline & $\begin{array}{c}\text { VNS } \\
\text { (Mean) }\end{array}$ & $\begin{array}{c}\text { EQ-5D } \\
\text { (Mean) }\end{array}$ \\
\hline Pre-procedure & $8.70 \pm 0.67$ & $4.40 \pm 0.51$ \\
\hline Early post procedure & $1.60 \pm 0.51$ & \\
\hline 1 month follow up & $2.10 \pm 0.87$ & $7.50 \pm 1.08$ \\
\hline 6 months follow up & $2.90 \pm 1.28$ & $6.60 \pm 1.26$ \\
\hline
\end{tabular}

Statistically significant differences were observed between the pre-treatment and post-treatment VNS and EQ-5D measures (Table III). The improvements in VNS scores were correlated with improvements in the EQ-5D scores with respect to the results in correlation tests ( $p$ value between pre-op EQ-5D and 6th month VNS: 0.546; $p$ value between pre-op VNS and 6th month EQ-5D: 0.508), and the 1st month and 6th month VNS and EQ-5D scores correlated significantly with each other $(\mathrm{p}<0.0001)$.

The VNS scores in the early post-procedure period had an effect on first month follow-up VNS $(p=0.011)$ and on the 6th month follow-up VNS $(p=0.020)$ respectively. Sixth month VNS scores and first month EQ-5D also had a significant effect on the 6th month EQ-5D scores (p: 0.021 and $\mathrm{p}<0.0001$, respectively). When the VNS and EQ-5D scores were evaluated with respect to the ages of patients, gender, and pre-procedure trauma existence and preprocedure VNS and EQ-5D scores, there were no significant differences except the effect of age on the pre-op EQ-5D score (p:0.043) (Table IV).

\section{DISCUSSION}

Coccdynia is a problem affecting patients' quality of life and it is frequently underestimated by physicians. It usually responds well to conservative management such as NSAIDs, wedge or doughnut cushions, manipulation and physical therapy. Steroid and local anesthetic injections to the sacrococcygeal area and coccyx are reported to be a successful measure, especially in patients with acute pain ( $<6$ months) (8). The blockade of ganglion impar (ganglion of Walther), the lowest node in the paravertebral sympathetic chain, has been reported to relieve chronic perineal pain $(9,12)$. Ganglion impar block provides immediate pain relief and 50-

Table III: Correlations of the Pre-Op VNS, Post-Op VNS, 1st Month VNS, 6th Month VNS, Pre-Op EQ-5D, 1st Month EQ5D and 6th Month EQ-5D Scores

\begin{tabular}{|l|c|c|c|c|l|c|c|c|}
\hline & \multicolumn{4}{|c|}{ VNS } & \multicolumn{4}{c|}{ EQ-5D } \\
\hline & Pre-op & Post-op & $1^{\text {st }}$ month & $6^{\text {th }}$ month & & Pre-op & $1^{\text {st }}$ month & $6^{\text {th }}$ month \\
\hline Pre-op & - & 0,275 & 0,877 & 0,546 & Pre-op & - & 1,000 & 0,508 \\
\hline Post-op & 0,275 & - & 0,073 & 0,455 & $1^{\text {st }}$ month & 1,000 & - &, 000 \\
\hline $1^{\text {st }}$ month & 0,877 & 0,073 & - & 0,000 & $6^{\text {th }}$ month & 0,508 & 0,000 & - \\
\hline $6^{\text {th }}$ month & 0,546 & 0,455 & 0,000 & - & & & & \\
\hline
\end{tabular}

** Correlation is significant at the 0.01 level (2-tailed). 
Table IV: The Effects of the Gender, Age, Trauma, Pre-Op VNS, Post-Op VNS, 1st Month VNS, 6th Month VNS, Pre-Op EQ-5D, 1st Month EQ-5D and 6th Month EQ-5D to the Pre-Op VNS and EQ-5D, Immediate, Short-Term and Long-Term Results of the Patients and Their Descriptive Statistics (Regression is Significant at the 0.05 Level)

\begin{tabular}{|c|c|c|c|c|c|c|c|c|c|c|}
\hline VNS & EQ-5D & & & & & & & & & \\
\hline & Gender & Age & Trauma & Pre-op & Post-op & $1^{\text {st }}$ month & $6^{\text {th }}$ month & Pre-op & $1^{\text {st }}$ month & $6^{\text {th }}$ month \\
\hline Pre-op VNS & 0,441 & 0,542 & 0,456 & - & - & - & - & - & - & - \\
\hline Post-op VNS & 0,963 & 0,495 & 0,783 & 0,356 & - & - & - & 0,952 & - & - \\
\hline $1^{\text {st }}$ month VNS & 0,936 & 0,278 & 0,825 & 0,767 & 0,011 & - & - & 0,680 & - & - \\
\hline $6^{\text {th }}$ month VNS & 0,542 & 0,146 & 0,990 & 1,000 & 0,020 & 0,008 & - & 0,899 & 0,772 & 0,021 \\
\hline Pre-op EQ-5D & 0,422 & 0,043 & 0,371 & - & - & - & - & - & - & - \\
\hline $1^{\text {st }}$ month EQ-5D & 0,623 & 0,084 & 0,836 & 0,911 & 0,539 & - & - & 0,180 & - & - \\
\hline $6^{\text {th }}$ month EQ-5D & 0,351 & 0,149 & 0,441 & 0,861 & 0,800 & 0,837 & 0,021 & 0,140 & 0,000 & - \\
\hline mean \pm SD & $\begin{array}{c}\% 80 \\
\text { female }\end{array}$ & $\begin{array}{c}49,20 \pm \\
14,43\end{array}$ & $\% 40$ & $\begin{array}{c}8,70 \pm \\
0,67\end{array}$ & $\begin{array}{c}1,60 \pm \\
0,51\end{array}$ & $\begin{array}{c}2,10 \pm \\
0,87\end{array}$ & $\begin{array}{c}2,90 \pm \\
1,28\end{array}$ & $\begin{array}{c}4,40 \pm \\
0,51\end{array}$ & $\begin{array}{c}7,50 \pm \\
1,08\end{array}$ & $\begin{array}{c}6,60 \pm \\
1,26\end{array}$ \\
\hline
\end{tabular}

$75 \%$ pain relief per injection lasting weeks to months in coccydynia patients (1). Destruction of ganglion impar with chemical neurolysis, cryoablation or RFT was also described for pelvic pain. The potential risks for chemical neurolysis are motor, sexual, bowel, or bladder dysfunction. The development of neuritis and neuralgia is another risk after any chemical neuroablative procedure $(6,9,11)$. Cryoablation is an alternative technique. Namely, $\mathrm{N} 2 \mathrm{O}$ or $\mathrm{CO} 2$ gas is used to cool the probe tip to approximately $-60^{\circ} \mathrm{C}$, forming an ice ball in the surrounding tissue. It is good for small, welllocalized lesions and it has lower incidence of neuritis and neuroma formation compared with chemical neurolysis (6). Radiofrequency treatment is a percutaneous minimally invasive procedure. Its widespread use and availability makes us consider it as a good option for the safe destruction of ganglion impar (11). Coccygectomy can be performed in patients resistant to conservative treatment and injections, particularly in patients with sacrococcygeal instability and hypermobility $(2,8)$. Dynamic standing and seated radiographs can demonstrate subluxation and hypermobility of the coccyx thus providing objective evidence of an organic lesion (7). Standing and sitting radiographs were not compared in our patients. The patients were satisfied with ganglion impar destruction; therefore, there was no need to consider coccygectomy for them.
Coccydynia is a relatively uncommon condition and it usually responds well to conservative treatment. Our study population of ten patients may not be enough for significance but there are only a few coccydynia patients treated by ganglion impar blockade or destruction reported in the literature. Conservative treatment modalities had failed to provide lasting pain relief in our patients. Ganlion impar block has been shown to benefit patients with chronic perineal pain (11-13). Successful blockade of the ganglion naturally depends on accurately locating the ganglion. The exact location of the ganglion impar is variable, but it is reported to be more frequently located inferior to the sacrococcygeal joint (9). We had performed ganglion impar blocks before RFT in order to confirm the location of the ganglion.

Ganglion impar block was first described with an anococcygeal approach $(10,13)$. Sacrococcygeal and transcoccygeal approaches were subsequently described. These techniques avoid the invasion of caudal tissues with lesser risk of irritation and are reported to be more tolerable to the patients $(4,13)$. We used the C1-C2 transcoccygeal approach in 9 patients, and we performed the transsacrococcygeal approach after the transcoccygeal approach had failed in one patient. This transcoccygeal approach was simple and had predictable results.

RFT of ganglion impar significantly improved both VNS and EQ-5D scores in correlation. The 
patient with an unsatisfactory result had a history of trauma with symptoms for 10 years and the patient with 50\% VNS score improvement (8 to 4 ), who was accepted as a successful result, also had a history of trauma with symptoms for 4 years. This long duration of symptoms and history of trauma might have affected the outcome in those patients. The effect of duration of symptoms on outcome should be investigated in a larger group of patients.

In conclusion, our results with this limited group of patients indicate that intercoccygeal/ transcoccygeal RFT of ganglion impar may provide successful relief in the treatment of chronic coccydynia. It is a simple and relatively safe procedure that should be considered in chronic coccydynia patients unresponsive to conservative treatment for at least 6 months.

\section{REFERENCES}

1. Buttaci JC, Foye PM, Stitik TP: Coccydynia successfully treated with ganglion impar blocs: A case series. Am J Phys Med Rehabil 84:218,2005

2. Cebesoy O, Guclu B, Kose KC, Basarir K, Guner D, Us AK: Coccygectomy for coccydynia: Do we really have to wait? Injury 38:1183-1188,2007

3. Fogel GR, Cunningham PY 3rd, Esses SI: Coccygodynia: Evaluation and management. J Am Acad Orthop Surg 12:4954,2004
4. Foye PM, Buttaci CJ, Stitik TP, Yonclas PP: Successful injection for coccyx pain. Am J Phys Med Rehabil 85:783-784,2006

5. Hodges SD, Eck JC, Humpreys SC: A treatment and outcome analysis of patients with coccydynia. Spine J 4:138-140,2004

6. Loev M, Varklet VL, Wilsey BL, Ferrante M: Cryoablation: A novel approach to neurolysis of ganglion impar. Anesthesiology 88:1391-1393,1998

7. Maigne JY, Lagauche D, Doursounian L: Instability of the coccyx in coccydynia. J Bone Joint Surg Br 82:1038-1041,2000

8. Mitra R, Cheung L, Perry P: Efficacy of fluoroscopically guided steroid injections in the management of coccydynia. Pain Physician 10:775-778,2007

9. Oh CS, Chung IH, Ji HJ, Yoon DM: Clinical implications of topographic anatomy on the ganglion impar. Anesthesiology 101:249-250,2004

10. Plancarte R, Amescua C, Patt RB, Aldrete JA: Presacral blockade of the ganglion of Walther (ganglion impar). Anesthesiology 73:751,1990

11. Reig E, Abejón D, del Pozo C, Insausti J, ContrerasR: Thermocoagulation of the ganglion impar or ganglion of Walther: Description of a modified approach. Preliminary results in chronic, nononcological pain. Pain Pract 5:103110,2005

12. Toshniwal GR, Dureja GP, Prashanth SM: Transsacrococcygeal approach to ganglion impar block for management of chronic perineal pain: A prospective observational study. Pain Physician 10:661-666,2007

13. Wemm K, Saberski L: Modified approach to block the ganglion impar (ganglion Walther). Reg Anesthe 20:544,1995

14. Wray CC, Easom S, Hoskinson J: Coccydynia. Aetiology and treatment. J Bone Joint Surg Br 73:335-338,1991 